Supplement of The Cryosphere, 8, 1577-1587, 2014

http://www.the-cryosphere.net/8/1577/2014/

doi:10.5194/tc-8-1577-2014-supplement

(C) Author(s) 2014. CC Attribution 3.0 License.

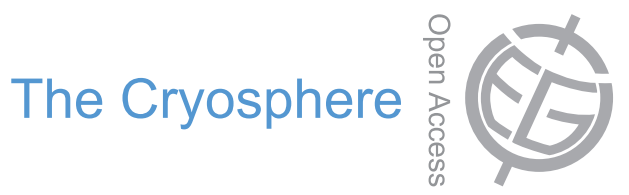

(c) (i)

Supplement of

\title{
How much snow falls on the Antarctic ice sheet?
}

C. Palerme et al.

Correspondence to: C. Palerme (cyril.palerme@lgge.obs.ujf-grenoble.fr) 


\section{Fractional coverage (\%)}
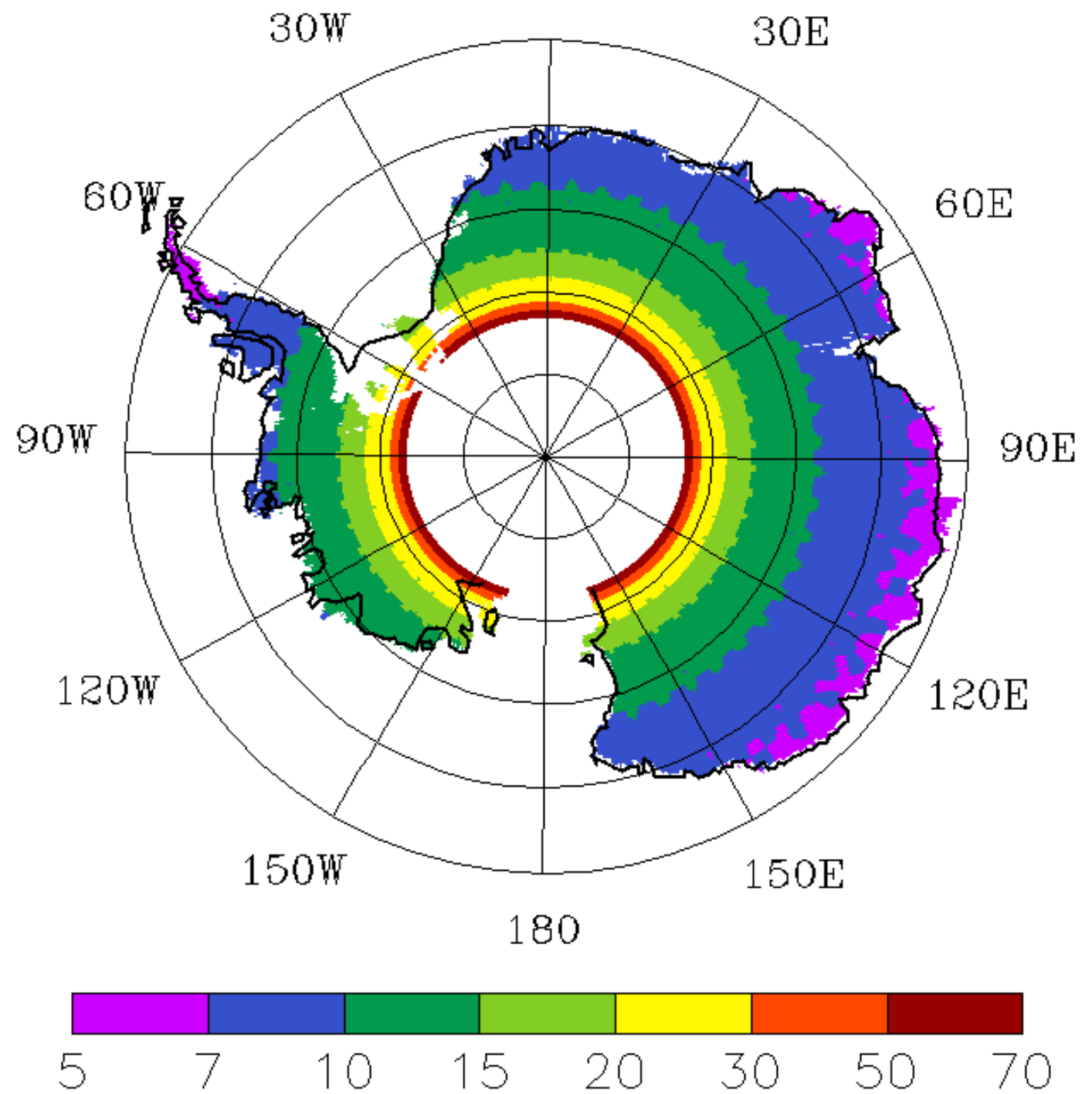

Fig. S1. Fractional coverage (\%) of the CloudSat ground tracks (ratio of the surface of the CloudSat ground tracks over the surface of the ice sheet).

Overall, the fractional coverage of the CloudSat ground tracks is relatively low. Nevertheless, in this study, statistics are obtained by averaging CloudSat data over 4.7 years, and this map has to be compared with the map of the number of orbits per grid cell (Fig. $1 \mathrm{a}$ ).

Because there is no convective precipitation in Antarctica, precipitating systems occur at a large scale, and the fractional coverage should not be an issue, except over the mountainous areas, where small scale orographic precipitation can occur. These areas are the Peninsula, the Vinson massif $\left(78^{\circ} \mathrm{S}, 85^{\circ} \mathrm{W}\right.$ ), and the Prince Charles Mountains (around $72^{\circ} \mathrm{S}, 65^{\circ} \mathrm{E}$ ).

Moreover, because of the CloudSat orbit, the spatial sampling is better in the grid cells along the latitude than along the longitude. In Antarctica, the spatial pattern of precipitation is characterized by a precipitation gradient along the latitude, thus this should be well represented by averaging the CloudSat data. 